\title{
ESPECIFICIDADES DO CONTRATO DE TRABALHO DESPORTIVO E O PACTO DE OPÇÃO NO ORDENAMENTO JURÍDICO PORTUGUÊS
}

\author{
SPECIFICITIES OF THE SPORTS WORK CONTRACT AND THE \\ OPTION PACT IN THE PORTUGUESE LEGAL ORDER
}

Rui Carmo Oliveira ${ }^{1}$

Tainá Penteado DalaRosa ${ }^{2}$

\begin{abstract}
RESUMO: O objetivo do presente estudo é ressaltar algumas das principais diferenças existentes entre o regime laboral português comum e o desportivo, de forma que se possa proceder ao correto enquadramento da análise do pacto de opção como parte integrante do contrato de trabalho desportivo. Dentre elas, estão questões relacionadas com a duração, período experimental, tempo de trabalho, poder disciplinar, liberdade, pacto de concorrência, empréstimo ou cedência, direitos de reintegração e arrependimento, condições resolutivas e intervenção de empresário. Neste sentido, cabe mencionar cronologicamente as previsões legais das regras que regem este tipo de contrato, que se vem desenvolvendo cada vez mais com a função de acompanhar os desafios modernos no que tange à oferta e à procura dos praticantes desportivos.
\end{abstract}

Palavras-chave: Especificidades. Contrato de trabalho desportivo. Pacto de opção.

ABSTRACT: The purpose of this study is to highlight some of the main differences between the Portuguese labor and employment law and the sports law, to frame the option pact as part of the sports employment contract. Among them, there are issues related to duration, probationary period, working time, disciplinary power, freedom, competition pact, loan or assignment, reintegration and repentance rights, resolving conditions and entrepreneur intervention. For this, is necessary to mention chronologically the legal provisions of the rules that govern this kind of contract, which

\footnotetext{
${ }^{1}$ Licenciado em Direito pela Faculdade de Direito da Universidade Lusófona, Mestre em Direito das Empresas e do Trabalho pelo ISCTE-IUL (Instituto Universitário de Lisboa), Professor Assistente nas disciplinas de Introdução ao Direito e Direito do Trabalho na Faculdade de Direito da Universidade Lusófona, Diretor de Clientes e Stakeholders da EDP, S.A. (Energias de Portugal). ORCID: https://orcid.org/0000-0003-3441-3834.

2 Graduada em Direito pela UniBrasil, pós-graduada em Justiça Administrativa e Fiscal pela Universidade de Coimbra e em Ciências Jurídico-Empresariais pela Universidade de Lisboa, aluna do Curso de Verão em Direito Internacional Privado, na Academia de Direito Internacional de Haia (Turma 2009), Mestranda em Direito das Empresas e do Trabalho no ISCTE-IUL (Instituto Universitário de Lisboa). E-mail: tainapenteadodr@gmail.com. ORCID: https://orcid.org/0000-0002-5420-0396.
} 
has been developing more to keeping up with modern challenges regarding the supply and demand of athletes.

Key words: Specificities. Sports employment contract. Option pact.

Sumário: 1. Introdução: Cronologia. 2. Duração do contrato. 3. Período experimental. 4. Tempo de trabalho. 5. Poder disciplinar. 6. Liberdade de trabalho. 7. Variabilidade da retribuição. 8. Cedência temporária de praticantes desportivos. 9. Dever de ocupação efetiva. 10. Incumprimento contratual. 11. Reintegração. 12. Direito de arrependimento. 13. Aposição de condição resolutiva no contrato desportivo. 14. Empresário: o "terceiro homem". 15. O pacto de opção. 16. Conclusão. 17. Referências.

\section{INTRODUÇÃO: CRONOLOGIA}

Uma primeira abordagem destes pontos atinentes ao contrato de trabalho desportivo surgiu em 1991, através da Convenção Coletiva de Trabalho outorgada pela Liga Portuguesa de Futebol Profissional e pelo Sindicato dos Jogadores Profissionais de Futebol. Posteriormente, em 1999, as mesmas entidades outorgaram outra convenção, que sofreu a mais recente atualização em 2017, através do Contrato Coletivo de Trabalho publicado no Boletim do Trabalho e Emprego no 8, de 28/02/2017.

Relativamente às leis, o primeiro regime jurídico próprio para os praticantes desportivos foi criado em 1995 (Decreto-Lei 305/95 de 18 de Novembro), posteriormente revogado pela Lei 28/98, de 26 de Junho, cujo conteúdo estabelecia as diretrizes dos contratos de trabalho do praticante desportivo e de formação desportiva.

Esta lei foi também revogada - pela atual Lei no 54/2017, de 14 de Julho - que prevê ainda, o regime jurídico aplicável ao contrato de representação ou intermediação.

\section{DURAÇÃO DO CONTRATO}

Como é sabido, o modelo laboral comum (embora consideradas algumas exceções cada vez mais significativas), assenta na regra da contratação por tempo indeterminado, conforme redação do artigo 140 do Código do Trabalho (CT). 
No entanto, a rigidez dessa regra mostra-se claramente desajustada à realidade laboral desportiva, na qual, devido ao carácter temporário e à própria natureza da atividade (de desgaste rápido e que requer uma condição atlética exigente) deve ser, sem qualquer exceção, a da contratação a termo (Art. $9^{\circ}$ e Art. $6^{\circ}$, no 3, 'f') da Lei 54/2017).

Este contrato a termo mostra-se deveras proveitoso do ponto de vista do praticante desportivo no sentido em que lhe garante segurança durante o período de vigência do contrato e resguarda a sua liberdade contratual. Ou seja, expirado o prazo do contrato, este pode desvincular-se da entidade para a qual prestava sua atividade e vincular-se a outra que lhe apresente melhores condições laborais.

$\mathrm{Na}$ ótica da entidade empregadora, acaba por revelar uma "função estabilizadora", pois garante o cumprimento do contrato celebrado durante o período convencionado, assegurando o equilíbrio dessa relação sinalagmática. Indo mais além, restringe a eventual concorrência permanente entre entidades empregadoras no que diz respeito à contratação dos praticantes e permite o equilíbrio e a boa organização das competições desportivas.

$\mathrm{O}$ agumento é relevante, ainda mais num sistema como o nosso, em que são proibidos os despedimentos sem justa causa - não se podendo rescindir o contrato ante tempus - e no qual a duração indeterminada poderia mostrar-se desmedidamente rígida.

Não se encontra, no entanto, qualquer obstáculo à celebração sucessiva de contratos a termo entre mesma entidade empregadora e praticante desportivo, o que claramente não se verifica nos contratos laborais comuns (Art. 179 do Código do Trabalho).

Relativamente ao período máximo de duração do contrato de trabalho desportivo, o já mencionado Art. $9^{\circ}$ da nova lei fixou-o em cinco épocas, reduzindo o anteriormente estabelecido pela Lei 28/98, de oito épocas. No caso de o praticante ainda ser menor, este prazo reduz para três épocas.

Sobre o período mínimo de vigência do contrato, existem duas exceções à regra do $\mathrm{n}^{\circ} 1$ do Art. $9^{\circ}$, quando estabelece que não pode ser inferior à uma época desportiva: nos casos em que a contratação tenha ocorrido após o início da época e para vigorar até 
o final desta, e quando o praticante for contratado apenas para determinada competição ou número limitado de prestações.

\section{PERÍODO EXPERIMENTAL}

De acordo com o estipulado pela lei do contrato de trabalho desportivo, o período experimental depende da estipulação expressa das partes e, ficando a cargo destas a fixação do tempo, não pode exceder 15 ou 30 dias, dependendo do período de duração total do contrato (respetivamente inferior a duas épocas desportivas, e superior a duas épocas).

Configura-se uma medida de precaução para ambas as partes, durante a qual podem livremente rescindir, sem necessidade de aviso prévio, de invocação de justa causa e sem qualquer direito ou dever a pagamento de indenização. Neste caso, há igualdade de previsão legal tanto no Código do Trabalho (Art. 114) como no regime do contrato de trabalho desportivo (Art. 23, 1).

Não resta dúvida, portanto, que é absolutamente plausível a utilização de uma "cláusula de experiência" no contrato de trabalho desportivo desde que acordado por ambas as partes. Neste sentido, o período de experimental não decorre de previsão legal para tal, mas da vontade expressa das partes, traduzida na redação de cláusula contratual específica para o efeito (Art. 6', 3, alínea 'g', da Lei 54/2017). Cabe mencionar que referido período tem carácter bilateral, pois estão em prova tanto o praticante desportivo, aos olhos da entidade empregadora, quanto esta, na ótica daquele.

No entanto, a grande questão em torno do período de experiência está ligada à sua admissibilidade.

Ora, como é sabido, a contratação de um praticante desportivo é sempre precedida de estudos cuidados e de um acompanhamento mais ou menos demorado, de forma a avaliar as suas aptidões. Não raras vezes, o praticante até se integra temporariamente nos quadros de uma potencial entidade empregadora, participando nos treinos, para facilitar a avaliação em curso. 
Adicionalmente, como ressalta João Leal Amado (2018), nas anotações à lei do contrato de trabalho desportivo, uma vez que o mercado de trabalho do desporto profissional é relativamente reduzido, possibilita-se um conhecimento quase que exaustivo das aptidões físico-técnicas por parte das entidades empregadoras, que além disso, possuem colaboradores cuja missão é exclusivamente detetar e avaliar as aptidões de possíveis praticantes para contratação.

Ademais, as consideráveis quantias monetárias geralmente envolvidas nas negociações contratuais apontam para uma necessidade de estabilidade e firme vinculação, não correspondentes com a facilidade de denúncia em período experimental.

Por fim, sobre este tema é ainda relevante mencionar a regra constante do Contrato Coletivo de Trabalho (CCT) já aludido. Do que já se falou acrescenta-se, através do seu Art. 11, que só poderá estabelecer-se período experimental no primeiro contrato celebrado entre mesmo jogador e mesmo clube; que referido período cessará imediatamente logo que o jogador seja utilizado em competição oficial, ou sofra, ao serviço do clube, lesão que o impeça temporariamente de praticar o futebol para além do termo do período experimental; e que não é admissível no contrato celebrado pelo jogador com o clube que the deu formação.

\section{TEMPO DE TRABALHO}

O Código do Trabalho estabelece nos seus artigos 198 e 203, além de outras especificações, que o tempo que o trabalhador se obriga a prestar é medido em número de horas por dia e por semana e que estas não devem exceder 8 horas diárias e 40 horas semanais (Período Normal de Trabalho), excetuando o banco de horas e adaptabilidade, nas suas facetas individual e grupal.

Diz ainda, no Art. 232, que o trabalhador tem direito a pelo menos um dia de descanso por semana, podendo não ser o domingo, embora esta regra venha acompanhada de cinco exceções. O duplo descanso, que hoje já não merece controvérsia, decorre dos usos laborais (como fonte de direito) e não do direito positivo. 
Trazendo essa realidade aos contratos desportivos, em muitos aspetos encontramos diferenças substanciais.

O Art. 16 da Lei 54/2017 esclarece o que se considera um período normal de trabalho para o praticante desportivo. Não é medido em horas de dias e semanas, mas no tempo em que está sob as ordens e na dependência da entidade empregadora, com vista à participação em provas desportivas, em tempo de sessões técnicas ou de treino, em estágios de concentração e viagens que precedam ou sucedam a participação em competições.

No entanto, apesar de ser considerado tempo normal, pelo facto de o praticante desportivo estar adstrito à subordinação do contrato, os estágios e viagens não são considerados para efeitos de duração máxima do trabalho, nos termos que estabelece a lei geral constante do Código do Trabalho, já aludido acima. Ou seja, para efeitos do cômputo das 8 horas diárias e 40 horas semanais como limite máximo do exercício da atividade, só se consideram os períodos de competição efetiva e de preparação e recuperação.

Conforme o $\mathrm{n}^{\circ} 4$ do já referido Art. 16, a regulamentação destes períodos de estágios fica a cargo dos contratos coletivos. Neste sentido, o artigo 21 do Contrato Coletivo "dos futebolistas" delimita que os estágios de concentração não deverão exceder trinta e seis horas (nos casos em que os jogos sejam realizados em campo próprio) ou setenta e duas horas (quando o jogo se for realizar em campo alheio, incluindo-se aqui o período de deslocação). No entanto, considera-se a possibilidade de alargamento do referido período quando as exigências da competição o justificarem.

Quanto ao descanso semanal do praticante desportivo, previsto no Art. 17 da Lei do Contrato do Trabalho Desportivo, este também tem direito a um dia, nos mesmos termos da lei geral, mas que pode quase nunca coincidir com o domingo. Deve, no entanto, ser sempre o dia posterior ao de competição, ou ainda, se não for possível, em dia acordado com a entidade empregadora para tal. Em caso de não acordo, realiza-se no primeiro dia disponível e pode ser sempre deslocado, mas nunca suprimido. 
Relativamente aos feriados obrigatórios e facultativos, estipulados nos Art. 234 e 235 do CT, o praticante desportivo também a estes têm direito e, embora possa não gozar no próprio dia por limitações relativas a competições agendadas, pode transferilo para outro dia.

Sobre férias, remete-se à lei geral.

No entanto, como complemento, os artigos 25, 26 e 27 da Convenção Coletiva de Trabalho em questão esclarecem pontos pertinentes, que não serão abordados no âmbito deste trabalho, não deixando, no entanto, de sublinhar a sua existência.

\section{PODER DISCIPLINAR}

Conforme Art. 98 do CT, o empregador exerce poder disciplinar sobre o trabalhador ao seu serviço, enquanto durar o contrato de trabalho e o elenco das possíveis sanções a serem aplicadas sob esta alçada estão previstas no Art. 328. O poder disciplinar do empregador, no Código do Trabalho, coexiste com o poder de direção e o poder regulamentar.

Como bem ressalta João Leal Amado, na obra já referida, o artigo 18 da lei específica dos praticantes desportivos contempla a maioria das sanções também aplicadas na lei geral supracitada, mas exclui duas que julga serem desmedidas para a realidade desportiva, que são a repreensão simples e a perda de dias de férias.

A primeira por poder ser considerada uma atuação normal exercida pelo treinador no curso da orientação e preparação do praticante, e a segunda, por ser inadequada num domínio tão intenso e desgastante quanto o de um atleta.

No entanto, não se exclui a possibilidade de o CCT prever outras sanções não prejudiciais nem incompatíveis com a lei, ao contrário do Código do Trabalho, em que as sanções a aplicar em sede de procedimento disciplinar são taxativas.

Cabe ressaltar que as sanções disciplinares devem ser aplicadas como resultado de um procedimento disciplinar, no qual tenham sido garantidas ao arguido as adequadas garantias de defesa, e devem ser proporcionais à gravidade da infração e à culpabilidade 
do infrator, não podendo aplicar-se mais de uma pena pela mesma infração (princípio do ne bis in idem).

Após iniciado o processo disciplinar, a entidade pode entender por suspender o praticante desportivo se a sua presença se mostrar inconveniente, mas não pode, de todo, suspender o pagamento da devida retribuição. O referido processo prescreve se, passados 180 dias da sua instauração, o infrator não tiver sido notificado da decisão final.

\section{LIBERDADE DE TRABALHO}

A redação do Art.19 da lei específica visa assegurar a liberdade do praticante desportivo (após a cessação do contrato anterior, qualquer tenha sido o motivo da rutura) em vincular-se a outra entidade empregadora, sendo nulas quaisquer cláusulas que contemplem pactos de não concorrência ou de preferência. Em sentido oposto é a previsão da lei geral, conforme $\mathrm{n}^{\mathrm{o}} 2$ do Art. 136, nos casos que se configurem necessários.

Ou seja, qualquer previsão que limite ou condicione a liberdade do praticante desportivo após o termo do contrato é nula, nos termos do $\mathrm{n}^{\circ} 1$ do Art. $19^{\circ}$.

Sobre este assunto, mais adiante abordar-se-á a questão do pacto de opção que também pode ser trazido a esta "série" das limitações, consoante a interpretação que lhe é dada.

Relativamente ao $\mathrm{n}^{\circ} 2$, prevê o pagamento de justa compensação a título de promoção ou valorização de jovem praticante por parte da nova entidade empregadora à antiga.

Aos olhos de João Leal Amado, esta previsão poderia vincular negativamente a liberdade contratual do praticante pois, ao mesmo tempo que pode representar um reconhecimento da entidade anterior pelo tempo que despendeu com a formação do atleta, pode ainda culminar em eventual não contratação por nova entidade, uma vez que implicaria um gasto superior ao da simples contratação, ou ainda, concretizando-se o 
negócio, poderia significar considerável diminuição na remuneração do atleta, visto o montante desembolsado a título de compensação.

No entanto, o $\mathrm{n}^{\circ} 2$ do Art. 19 deixa a cargo dos contratos coletivos de trabalho essa previsão, sendo que aqui apenas autoriza que aconteça e impõe limites, entre os quais o de que as transferências só podem ocorrer entre entidades empregadoras portuguesas com sede em território nacional.

Esta limitação resulta, de certa forma, como salvaguarda relativamente ao Acórdão Bosman (TJUE, 15.12.1995) que constatou serem as "indenizações de transferência, formação ou promoção" um entrave injustificado à livre circulação dos futebolistas no espaço da União Europeia, entre Estados-membros.

Revela-se pertinente, no entanto, fazer uma breve diferenciação do que seria uma indenização por transferência de uma compensação pela formação. $\mathrm{Na}$ indenização, o clube adquirente deveria sempre despender uma quantia como forma de libertar o praticante desportivo do vínculo anterior, enquanto a compensação pela formação seria uma recompensa à entidade que se dedicou à formação do atleta e não obteve os retornos do seu desenvolvimento profissional por este ter sido transferido precocemente.

\section{VARIABILIDADE DA RETRIBUIÇÃO}

Os contratos desportivos, como já se pôde depreender, são repletos de especificidades, e uma delas é a validade da cláusula que prevê o aumento ou mesmo a diminuição da remuneração do praticante em caso de subida ou descida de escalão competitivo da entidade empregadora, nos termos do Art. 15, 2 da Lei 54/2017 (v.g. Art. 35 do CCT dos futebolistas).

Também é descabida a aplicação do princípio geral constante do Art. 270 do CT como critério para a determinação da retribuição com o argumento de "trabalho igual ou de valor igual, salário igual”, mesmo numa interpretação jurídica da norma em que a igualdade é tratar de forma igual o que é igual e diferente o que é diferente, na medida 
dessa diferença. Cai igualmente por terra o princípio da irredutibilidade da retribuição, tão relevante no direito do trabalho "comum".

Ora, neste mundo desportivo onde cada atleta é único e assim devidamente considerado, apesar de desempenharem a mesma atividade, certamente não realizam da mesma forma e com a mesma técnica, eficiência e visibilidade. Se formos para o âmbito dos clubes de futebol, não pouco comum são os salários de cada jogador dentro do mesmo clube serem diferentes, consoante inúmeros aspetos relevantes que devem ser considerados, individualmente.

\section{CEDÊNCIA TEMPORÁRIA DE PRATICANTES DESPORTIVOS}

Instituto visto com pouquíssima simpatia pela lei laboral comum, a cedência de praticantes é amplamente utilizada no âmbito dos contratos desportivos.

Tem sua proibição prevista no Art. 288 do Código do Trabalho (embora admita as exceções dos Art. 289 a 293) e sua regulamentação no Art. 20 da lei do contrato do trabalho desportivo, determina os moldes do que se conhece por “empréstimo".

Neste caso, a entidade empregadora cede provisoriamente um trabalhador a outra entidade, mantendo, no entanto, a sua posição contratual. O que ocorre é uma deslocação de poderes e deveres patronais para a entidade cessionária, não perdendo, no entanto, a entidade cedente, o vínculo jurídico-laboral.

Daqui se depreende, como alude Albino Mendes Baptista (2006), que acaba por se tratar de um negócio trilateral, pois satisfaz interesses relevantes das três partes: o praticante, o empregador-cedente e utilizador-cessionário.

No âmbito do empregador-cedente, significa uma redução de custos com os atletas, pois transmite a responsabilidade do pagamento das retribuições à outra entidade; uma melhor gestão da equipa (em caso de desportos coletivos) conforme as opções de diferentes treinadores; um amadurecimento desportivo e a aquisição de ritmo competitivo do praticante (processos de formação). 
Para o utilizador-cessionário, significa obter serviços de praticantes desportivos que de outro modo poderia não alcançar, um maior equilíbrio da equipa com recurso a jogadores de mais-valia e uma melhor e mais rápida resposta a eventuais exigências técnicas.

$\mathrm{Na}$ ótica do praticante desportivo cedido, pode corresponder à participação ativa em competições (que na outra entidade poderia não conseguir) e a um amadurecimento profissional, assim como valorização pessoal.

O contrato de cedência, devendo ser realizado de comum acordo pelas três partes, deve conter a declaração expressa de concordância do praticante cedido, a duração da cedência (contemplando ou não cláusula de eventual regresso antecipado) e pode estabelecer condições remuneratórias diversas das acordadas com a entidade cedente, desde que não envolva diminuição da retribuição.

\section{DEVER DE OCUPAÇÃO EFETIVA}

Por este dever, entende-se a utilização efetiva que o praticante desportivo tem dentro da sua entidade empregadora. Neste sentido, por exemplo, nos casos dos clubes de futebol, importa estar atento a um afastamento eventualmente abusivo do praticante desportivo do seu grupo normal de trabalho, ou ainda, a sua utilização indevida nas "equipas B".

É necessário, aqui chegados, avaliar "caso a caso" tendo em conta o "poder de direção do empregador" e os "limites da boa fé".

Conforme entende Baptista, há a consagração legal de uma justa causa desportiva, na qual, nos termos do Art. 15 do Regulamento da FIFA relativo ao Estatuto e Transferência dos Jogadores, por exemplo, um profissional que, no decorrer da época tenha participado em menos de $10 \%$ dos jogos oficiais em que seu clube esteve envolvido, pode rescindir o contrato antes do seu termo por justa causa. No entanto, há a ressalva de que o profissional só pode rescindir o contrato com este fundamento dentro de 15 dias após o último jogo oficial da época do clube em que está inscrito. 
Neste caso não se reconheceria a justa causa como sendo um comportamento culposo do clube (como prevê o Art. 23, 3 da Lei 54/2017), mas pelo interesse do atleta de forma a proteger sua carreira desportiva. Assim sendo, não caberia qualquer direito ou dever a indenização.

O dever de ocupação efetiva (ou direito, se visto na ótica do trabalhador desportivo) foi consagrado na legislação espanhola e posteriormente na portuguesa. $\mathrm{O}$ Regulamento Deportivo 1006/1985, no número 4 do artigo $7^{\circ}$, previa o que já era consagrado pelo Estatuto de los Trabajadores, o dever do empregador em proporcionar ao trabalhador desportivo uma ocupação efetiva.

Em Portugal, a Lei no 28/98, que regulava a relação laboral-desportiva, na alínea a) do artigo 12, consagrou este direito antes mesmo da legislação comum, que hoje o contempla, na alínea b) do artigo $129^{\circ}$ do Código do Trabalho. Adicionalmente, este dever está também positivado nos artigos 12 e 14 do CCT. ${ }^{3}$

E antes da previsão deste dever no Código do Trabalho português, já a doutrina e a jurisprudência pátria se pronunciavam maioritariamente a favor do modelo que a Lei acabou por consagrar. Quando colocamos essa questão à luz da realidade do trabalhador desportivo, ganha novos contornos.

Para um atleta profissional, a falta de uma ocupação efetiva, strictu sensu, pode ser ainda mais prejudicial do que para trabalhadores comuns. $\mathrm{O}$ atleta precisa estar em atividade para manter a forma física e aprimorar a técnica. Mais do que isso, sem jogar perde visibilidade e pode ter sua carreira prejudicada. António Monteiro Fernandes (2019) diz que "profissões há em que a prestação de trabalho efetivo corresponde a interesses importantes do trabalhador, podendo a inatividade injustificada - embora com retribuição - causar-lhe desvantagens profissionais e pessoais sérias".

No términus do contrato, o atleta que pouco jogou terá dificuldades acrescidas em renovar o vínculo com o clube, e até mesmo em negociar com outro empregador. Neste sentido, Leal Amado afirma que: “o praticante desportivo precisa de se exibir,

\footnotetext{
${ }^{3} \mathrm{Na}$ esteira dessa previsão, o dever de ocupação efetiva para o trabalhador desportivo está hoje consagrado na alínea b) do artigo 11 da Lei 54/2017.
} 
necessita de competir, sob pena de cair no esquecimento e/ou de ver desvalorizada a sua cotação no respetivo mercado de trabalho". Tal afirmação é, obviamente, mais relevante porque estamos perante uma "profissão concentrada, de curta duração e forte intensidade".

Podemos então concluir, apressadamente, que o dever de ocupação efetiva plasmado na alínea b) do artigo 11 da Lei 54/2017 é o dever de garantir, ipsis verbis, que o atleta jogue, que possa estar sempre envolvido nas competições em que se insere o seu empregador?

Antes de responder, negativamente, à pergunta anterior, importa distinguir duas dimensões da ocupação efetiva no contrato do trabalhador desportivo.

A dimensão propedêutica, garante que o trabalhador desportivo deve ter o direito de participar nos treinos e outras atividades preparatórias ou instrumentais para a competição desportiva. É a dimensão habilitante, que deve ser sempre garantida, salvo lesão ou incapacidade física temporária.

Aliás, se assim não fosse, estaríamos perante um putativo caso de assédio moral, previsto no artigo 12 da Lei 54/2017 e no artigo 24 do Código do Trabalho, o que poderia levar a resolução com justa causa do contrato de trabalho desportivo, caso se provasse.

$\mathrm{O}$ Clube/SAD/SDUQ 4 tem o poder de direção da prestação laboral (à imagem do poder de direção para o contrato de trabalho dito normal, como previsto no artigo $97^{\circ}$ do Código do Trabalho) e pode determinar quando e onde serão realizados os treinos e outras atividades preparatórias. A questão só conflitua com o dever de ocupação efetiva quando existem dois ou mais grupos de trabalho, onde o Clube/SAD/SDUQ determina que atletas constituirão cada um (agora de novo em voga, com as equipas B). Existem diferentes razões para que o empregador separe os atletas, mas o seu afastamento do grupo normal de trabalho pode ser considerado uma violação do dever de ocupação efetiva, principalmente se essa decisão se dá de forma a punir o atleta por alguma

\footnotetext{
${ }^{4}$ SAD (Sociedade Anónima Desportiva); SDUQ (Sociedade Desportiva Unipessoal por Quotas).
} 
indisciplina, não renovação ou recusa de cedência/resolução do contrato, e não por razões técnicas.

Nada a opôr, por princípio e sem dogmas, que se tome a decisão de colocar um atleta a treinar em separado, mas só quando esta medida tiver fundamentação técnica ou médica, como o aprimoramento da forma física, a recuperação pós-tratamento médico ou um treino específico para o atleta, como finalizações ou cruzamentos (à imagem do que hoje fazem, com sucesso, Jorge Jesus e José Mário Mourinho). Mas, o que pode acontecer - e infelizmente acontece no futebol - é o afastamento como punição por motivos menos claros, e esta atitude é a que se condena.

A dimensão de competição implica a participação do trabalhador desportivo em competições oficiais, ao serviço do seu empregador.

Só treinando o atleta se manterá em forma, e só jogando ele aparecerá como um artista aos olhos do público, com a consequente valorização.

No entanto, o que seria da autonomia do treinador se o jogador tivesse o direito efetivo de jogar em competições oficiais? E como seria isso compaginável, por exemplo, no futebol, com plantéis de 26 elementos em que só 11 (mais três substituições, 4 se existir prolongamento) podem jogar? O treinador é um gestor de recursos humanos: é ele que sabe quem são os jogadores que lhe dão mais condições técnicas/táticas para determinado jogo ou modelo de jogo e essa autonomia é absolutamente intocável.

O direito que a legislação garante ao atleta não é o de participar em jogos oficiais ou competições, mas somente o de não ser excluído, injustificadamente, de treinos e atividades preparatórias, dentro da dimensão habilitante/propedêutica. Não se pode confundir o direito de trabalhar com um direito de ser convocado para um jogo ou, muito menos, o direito de ser titular.

Tanto a lei portuguesa quanto a espanhola sublinham e exteriorizam o dever de ocupação efetiva do trabalhador desportivo apenas em relação à sua dimensão propedêutica. Cabe ao Clube/SAD/SDUQ, através dos responsáveis técnicos, nomeadamente o treinador e sua equipa técnica, decidir quais os atletas que jogam, os que vão para o banco de suplentes e os que nem sequer "calçam", vendo o jogo na 
bancada. Assim sendo, o direito à ocupação efetiva existe, mas é limitado, não é pleno. Ou seja, nas palavras de Leal Amado, "em termos muito simples, o praticante tem o direito de treinar, mas não o de jogar, tem o direito de se preparar, mas não o de competir, tem o direito de ser adestrado, mas não o de ser utilizado". Na mesma linha de pensamento, Albino Mendes Baptista defende que "A ocupação efetiva não significa qualquer direito a ser titular. O que o praticante não pode é ser impedido de treinar, integrar as sessões técnicas, teóricas e práticas, ou participar noutras atividades preparatórias ou instrumentais da competição desportiva” e Cardenal Carro (1996) sublinha que "como el contraria prejudique de alguna forma el trabajador, es possible afirmar que este derecho, entre los deportistas professionales, es impossible que se conceda".

O dever de ocupação efetiva não pode, assim, ultrapassar a propiciação das condições necessárias e suficientes à participação desportiva. Asseguradas estas condições, que constituem um requisito mínimo e obrigatório, o trabalhador desportivo exerce a sua atividade, e está preenchido o seu direito à ocupação efetiva (assim como, sinalagmaticamente, o dever homónimo do empregador), preparando-se para a competição, da qual fará parte não em função de uma especial imposição legal mas em função da excelência, do seu mérito próprio ou das características pessoais que o treinador valorize para determinado jogo, estratégia, desenho tácito, etc.

Em resumo, a atividade do trabalhador desportivo é essencialmente instrumental do jogo, embora o possa integrar. Mas o jogo é o seu elemento finalístico ou teleológico e não o seu núcleo essencial. A redução da previsão legal à dimensão propedêutica ou habilitante não decorre de uma impossibilidade contingente, mas antes da correta interpretação da natureza específica e particular da natureza da atividade profissional desportiva e não diminui, em nenhum momento, a consagração inequívoca do direito à ocupação efetiva do trabalhador desportivo.

\section{INCUMPRIMENTO CONTRATUAL}


O incumprimento contratual por qualquer das partes gera o direito de rescindir o contrato celebrado.

Para isso, o Art. 23 da lei específica elenca as formas de cessação do contrato desportivo, que podem vir a ser por caducidade, revogação por mútuo acordo, despedimento com justa causa por iniciativa do empregador, resolução com justa causa por iniciativa do praticante, denúncia em período experimental, despedimento coletivo, ou denúncia por iniciativa do praticante (se estipulado em contrato que o pode fazer, sem justa causa, e com o dever de indenizar a entidade - Art. 25).

Todas as formas acabam por suscitar grandes desdobramentos, no sentido de que podem sempre existir situações específicas que exijam um estudo mais detalhado.

Apenas um exemplo de sanção pelo incumprimento contratual seria a situação de despedimento pela entidade empregadora ou resolução por justa causa por iniciativa do praticante desportivo, no qual a parte que deu causa à cessação ou que haja promovido indevidamente, incorre em responsabilidade civil pelos danos causados, devendo pagar à contraparte o valor das retribuições que ao praticante seriam devidas se o contrato de trabalho tivesse cessado no seu termo (Art. 24 LCTD 2017).

\section{REINTEGRAÇÃO}

Apesar de prevista na antiga LCTD de 1998, e ainda constante na lei laboral comum, hoje já não está presente na Lei 54/2017 por se mostrar completamente desajustada à realidade desportiva.

Neste tipo de atividade, a confiança recíproca é de extrema importância, e uma vez quebrada, quer somente com o clube ou principalmente com os adeptos, não se vislumbra a possibilidade de uma reintegração de praticante desportivo à entidade empregadora que o tenha despedido sem justa causa.

\section{DIREITO DE ARREPENDIMENTO}


Também não é aplicável nestes tipos contratos, uma vez que na grande maioria dos casos as contratações são acompanhadas e/ou sugeridas por empresários e dotados de grande estudo por parte dos interessados.

Além disso, como bem alude Baptista, não se deve perturbar anormalmente as competições desportivas, nos fazendo crer na incompatibilidade de tal direito com as especificidades da relação laboral desportiva.

\section{APOSIÇÃO DE CONDIÇÃO RESOLUTIVA NO CONTRATO DESPORTIVO}

Sobre este assunto, a lei laboral é omissa e este silêncio, nas palavras de João Leal Amado, tem sido interpretado de forma negativa.

No entanto, no contrato do trabalho desportivo as situações devem ser analisadas por prismas distintos e mais abertos.

Efetivamente, o problema do risco do contrato não pode ser considerado nos mesmos termos de uma relação laboral comum, sendo absolutamente admissíveis cláusulas resolutivas específicas apostas pelos interessados, consoante a que pretendam condicionar a resolução do contrato, desde que não haja ofensa à lei.

Um exemplo dessa abertura de entendimento, referente à aposição de cláusulas resolutivas, acaba por ser a alínea d) do artigo 41 do CCT dos futebolistas, quando prevê que "o contrato de trabalho desportivo caduca verificando-se a condição resolutiva aposta no contrato, nomeadamente se for convencionada a extinção do contrato em caso de descida de divisão do clube ou sociedade desportiva, ou na eventualidade de determinada verba ser oferecida ao clube e ao jogador por parte de outro clube interessado nos seus serviços".

Ou seja, na opinião fundamentada do referido autor, "a condição resolutiva, que em geral se traduz num puro instrumento de precarização contratual, pode aqui assumir contornos de autêntico instrumento de libertação contratual para o praticante". 


\section{EMPRESÁRIO: O "TERCEIRO HOMEM"}

Hoje em dia a intervenção de empresários constitui uma das particularidades mais relevantes do contrato de trabalho desportivo. Não se conhece nada em paralelo no direito do trabalho. Acaba até por romper o princípio do direito laboral da proibição da intermediação na celebração de contrato de trabalho.

Com razão, Leal Amado chama a atenção para a emergência deste "terceiro homem" e para a "assunção, por parte do agente de um claro status de promotor dos interesses do praticante desportivo, de negotiation equalizer".

O empresário, por força do exercício das suas funções adquire competências que o habilitam a restabelecer a igualdade entre clube e desportista profissional. $\mathrm{Na}$ realidade, a condição de parte mais débil do trabalhador perante a entidade empregadora, que na lei laboral é considerada, perde aqui sua razão.

Tendo sido prevista já na LCTD anterior, a regulamentação dos empresários desportivos sofreu uma modernização com a nova Lei 54/2017, pois trouxe novas e melhores definições e limites à essa atuação (Art. 36 e seguintes). Uma dessas novas previsões é a necessidade de constar do contrato desportivo entre entidade e praticante a identificação do empresário desportivo que tenha intervindo no contrato.

Entre praticante e empresário, no entanto, deve haver também um contrato escrito que regulamente o vínculo entre as partes, preveja as condições de remuneração (que não pode exceder $10 \%$ do montante líquido da retribuição do praticante) e o termo do contrato (que não pode exceder dois anos, embora sejam admitidas renovações sucessivas por comum acordo, sendo vetadas cláusulas de renovação automática).

Do que já se abordou até agora, sobre as especificidades do contrato de trabalho desportivo, conclui-se que há uma clara e inequívoca necessidade de regras especiais para a sua regulamentação, conforme se tem observado ao longo dos anos. Neste sentido, é absolutamente salutar a evolução e atualização das normas que o delimitam e regem, visto afastar-se das regras laborais comuns. 
Daí também se depreende a ideia de que a autonomia das partes tem maior relevância, uma vez que podem adaptar os contornos dos contratos às reais e específicas necessidades, importando ponderar interesses ligados ao equilíbrio das competições desportivas e à estabilidade contratual. E nesta ponderação há que se considerar, então, a forte presença do empresário desportivo. Autonomia que no Direito do Trabalho dito comum, só encontramos em sede de direito coletivo.

Não se sugere uma arbitrariedade e/ou desproporcionalidade da fixação de condições contratuais, mas um maior equilíbrio em nome das especificidades desta modalidade de contrato de trabalho.

\section{O PACTO DE OPÇÃO}

O estudo desta previsão nos contratos desportivos faz-se no domínio do direito das obrigações, em regra, a propósito do pacto de preferência, com o qual, todavia, não se confunde.

O pacto de preferência em determinado contrato prevê que, aquando da sua celebração, este direito seja exercido. Já no pacto de opção, a declaração de uma das partes é aposta num contrato em formação para vigorar neste mesmo contrato.

Para Mário Júlio Almeida Costa (2009), o pacto de opção “consiste no acordo em que uma das partes se vincula à respetiva declaração de vontade negocial, irrevogável, correspondente ao negócio visado, e a outra tem a faculdade de aceitá-la ou não, considerando-se essa declaração da primeira uma proposta irrevogável".

Ou seja, o referido pacto é uma cláusula contratual aposta nos contratos desportivos, aquando da sua celebração (ou excecionalmente posteriormente celebradas) com a finalidade deixar clara a intenção de uma das partes em prorrogar o vínculo de trabalho. Em outras palavras: além do termo estabelecido para a caducidade de um contrato, uma das partes vincula-se a uma prorrogação por mais um determinado período, constituindo - esta opção - parte do contrato e nunca um negócio jurídico autónomo. 
Para João Leal Amado, referida previsão é tão restritiva da liberdade contratual quanto os pactos de não concorrência e de preferência ( $n^{\circ} 1$ do Art. 19 da nova LCTD).

Este autor considera que uma das partes se vincula completamente, numa perspetiva de sujeição, deixando-se à outra, inteira liberdade em aderir ou não à proposta contratual. Seria uma situação de resolução ad nutum, inválida em sede de contratos desportivos, com base na proibição dos despedimentos livres e da denúncia ante tempus.

Ocorre uma situação de exercício do direito potestativo por parte do beneficiário do pacto, que resulta em uma prorrogação unilateral da relação contratual que atinge seu termo.

Neste sentido, a previsão da opção seria uma forma de se tentar contornar essa proibição legal; um "mecanismo de defraudar as normas" do despedimento sem justa causa. No entanto, sendo a fraude uma situação patológica, não pode ser presumida, mas antes comprovada por quem alega, sob pena de se concluir pela sua inexistência.

Albino Mendes Baptista, por sua vez, entende que a questão deve ser colocada em outros termos: se forem definidos previamente os pressupostos do exercício do pacto de opção, seja o acesso a uma competição ou a manutenção de escalão competitivo, por exemplo, não se verificam motivos para aludir a negócio in fraudem legis. De resto, resultado semelhante poderia ser obtido através da aposição de uma cláusula resolutiva ou de uma condição suspensiva.

Assim, as partes podem celebrar, por exemplo, um contrato de trabalho por duas épocas desportivas prorrogável por mais uma se o clube aceder a uma competição europeia ou não descer de escalão competitivo. Neste plano, a situação não é diferente do pacto de opção a favor do clube se o seu exercício estiver ligado à verificação de pressupostos similares.

O exercício da opção funcionaria como a verificação da condição que dá eficácia ao contrato principal. A reserva de opção passaria assim a ser configurada como uma condição potestativa.

Para este autor, o que está em causa num contrato de trabalho desportivo é, sobretudo, a estabilidade contratual, em "sentido bidirecional": praticante desportivo - 
entidade empregadora, e que o não exercício do direito de opção não constitui uma rescisão do contrato, mas uma cessação pela verificação do seu termo.

Este tipo de contrato, mesmo com o pacto de opção, pode caducar no termo previsto, sem a necessidade de qualquer declaração nesse sentido. Nesta ótica, há caducidade do contrato e não despedimento; há a prorrogação de um vínculo préexistente e não a constituição de uma nova relação jurídica.

Não concorda, portanto, com a ideia de despedimento "ad nutum" defendida por João Leal Amado, pois a rutura de um contrato não pode ocorrer por dupla via: despedimento e caducidade. O não exercício do direito de opção não pode representar simultaneamente a constituição de uma relação jurídica e a sua extinção.

Para melhor elucidar o que aqui se tenta esclarecer, convém trazer os exemplos que Baptista utiliza no livro já referido, nos quais se pode observar argumentos em ambos os sentidos:

Exemplo 1: Celebração de contrato desportivo pelo prazo de dois anos entre praticante e entidade, com opção a favor do primeiro por mais uma época.

Neste caso, o praticante vincula-se por duas épocas enquanto o clube se vincula por três. Aqui o clube não tem garantido o vínculo até ao final da terceira época, o que significa que ao final da segunda época está a cargo do praticante a decisão da continuidade do vínculo.

Apela-se aqui para o princípio da liberdade contratual do praticante, que tem a autonomia para exercer a sua opção, ficando o clube em autêntica sujeição.

Exemplo 2: A meio da época, praticante e clube celebram contrato de trabalho até o fim desta, com direito de opção a favor do segundo por mais três épocas.

Neste caso, João Leal Amado entende há uma tentativa de driblar as normas legais do período experimental.

No entanto, Baptista interpreta que referido contrato pode ter tomado estes contornos em virtude da necessidade de avaliação de outras prioridades do empregador, como a gestão provisória do plantel, possível acesso à uma competição europeia, descida 
de escalão competitivo, eventual troca de treinador ou situação financeira na época seguinte, entre outras.

Aqui, deve entender-se que o pacto está ao serviço de outros interesses que não os relativos a período experimental.

Exemplo 3: Contrato celebrado entre praticante e clube por oito épocas (e atualizando-se à legislação atual, cinco épocas), com opção a favor do segundo por mais duas épocas.

Nesta situação, o pacto de opção deverá sim ser considerado inválido pois apresenta um cenário de sujeição do praticante a um vínculo que à partida, não deve ultrapassar o limite máximo de duração do contrato (oito épocas na LCTD antiga, cinco épocas na lei atualizada 54/2017).

Continuando neste entendimento, Baptista positiva que, relativamente aos praticantes desportivos de alto nível, a liberdade contratual é muito expressiva e manifesta-se por um acompanhamento cuidado dos empresários, que acabam por assegurar uma clara igualdade contratual entre desportista e empregador. Por isso, julga desajustado o entendimento de Amado, quando conclui pela invalidade do pacto de opção a favor do clube por considerar esta uma parte contratante mais forte e que se deve assegurar a tutela da mais débil delas, neste caso, o praticante.

Nestes termos, resulta que do trabalho desportivo importa não adotar esquemas de enquadramento único, mas antes atender a situações plurais que exijam soluções diferenciadas, tutelando quem precisa de proteção, mas sempre em moldes mais abrangentes e diversos, conferindo mais espaço contratual aos sujeitos.

Para se ter uma dimensão mais certeira das diversidades contratuais no domínio do desporto, basta verificar as consideráveis desigualdades retributivas dentro da mesma equipa, absolutamente incompatíveis com o princípio já mencionado de que para trabalho igual ou de igual valor, salário igual. Aqui, como no pacto de opção, é a lógica competitiva que funciona como pano de fundo.

Há inúmeros considerandos deste tipo de contratos que pressupõem uma tolerância diferente relativamente à liberdade contratual, na qual o contrato acaba por 
ser um instrumento de gestão de especificidade desportiva e de segurança da valorização de interesses mais específicos de maneira diferente.

Devem estar assegurados o equilíbrio de competições e a estabilidade das relações desportivas. Enquanto no direito do trabalho há uma rigidez no que tange a defesa dos direitos do trabalhador, no direito desportivo o foco é a segurança dos referidos interesses, mas em equilíbrio com a estabilidade da equipa (se for o caso) e das competições.

Outra questão que se coaduna é a da incerteza dos resultados e no caminho inerente ao desenvolvimento desta atividade. Diferentemente das relações de trabalho ditas normais, nas quais, em regra, domina o conjunto, nas relações desportivas relevase o talento individual.

Dessa forma, importa considerar a relevância do desportista dentro da equipa, se assim for, no que tange a obtenção de resultados, lesões, entre outras questões possam ser levantadas.

João Leal Amado reitera seu entendimento contrário à opção quando diz que referido pacto a favor do clube será sempre nulo (sem qualquer exceção!), devendo a cláusula do contrato ser substituída automaticamente pela norma imperativa violada e mantendo-se em vigor as restantes previsões contratuais, não acarretando a invalidade de todo o contrato.

Albino Mendes Baptista, no entanto, entende que mesmo que se conclua pela nulidade do pacto de opção estabelecido a favor do clube, não se deverá aplicar a substituição da norma (atual artigo 121, 2 do CT), mas antes dever-se-á recorrer em toda a sua extensão ao disposto no 292 do Código Civil, segundo o qual a nulidade parcial não determina a invalidade de todo o negócio, salvo quando se mostre que este não teria sido concluído sem a parte viciada.

Outro aspeto que merece ponderação é a circunstância de o pacto de opção não ser outorgado logo no momento da redação do contrato, mas a posteriori. Neste caso, seria uma cláusula que apesar de vinculada, estaria desligada do contrato inicial e seria resultado do desenvolvimento da relação de trabalho. 
Há quem entenda preferível esta hipótese por considerar que a cláusula inserida já no contrato que dá início à relação laboral poderia vincular e restringir a liberdade do praticante por se submeter de pronto a requisitos com vista a alcançar a contratação que naquele momento é do seu interesse, embora possa não querer limitar a sua atividade profissional no futuro (PINTO; MARTINS; CARVALHO, 1994).

Pertinente é também aludir à cláusula de opção recíproca, que na sequência do entendimento de BAPTISTA não suscita objeções.

Podem-se levantar questões de fraude à lei e também de despedimento ad nutum quando o clube opte por não exercer o direito de opção. Nesta situação, o praticante desportivo, se o pretender, tem garantida a contratação pelo período correspondente ao pacto de opção, assegurando o equilíbrio tão almejado da relação contratual. Por outro lado, se o clube exercer o direito de opção e o praticante pretender a desvinculação, aí então estará em situação de sujeição, o que resultaria na mesma condição de se ter estabelecido um pacto exclusivamente a favor do clube.

Importante é, uma vez aceite a validade do pacto de opção, atentar para as normas gerais e matéria de vícios de vontade, tais como erro, dolo, coação moral, incapacidade acidental, usura, entre outros, sem prejuízo da correta avaliação da autonomia negocial e da adequação do pacto de opção aos interesses em presença.

Acresce ainda a diferença entre as realidades empresarial desportiva e comum. Neste sentido, Amado alude à "peculiar lógica empresarial do desporto profissional."

Significativo também é aferir o exercício do direito de opção em situações de abuso de direito, como a que o praticante foi pouco utilizado em competições desportivas ou mesmo "excluído" do desenvolvimento normal das atividades laborais, ou ainda se o clube criar expectativas no praticante que o direito de opção será exercido e posteriormente não o fizer.

Em outro plano, também constituiria abuso de direito o comportamento do praticante que durante o contrato se conformou com o pacto de opção e que pouco antes do seu exercício considera-se desonerado de qualquer hipótese de prorrogação. 
Estes comportamentos atentam contra o investimento de confiança e são suscetíveis de corresponder a um venire contra factum proprium, que traduz no exercício de uma posição jurídica em contradição com uma conduta antes assumida ou proclamada pelo agente.

Acrescente-se que essa previsão é objetiva: não requer culpa por parte do titular, na ocorrência da contradição.

O exercício do direito de opção deve, pois, obedecer a pressupostos formais, nomeadamente a definição de um pré-aviso razoável, de modo a que a situação não prejudique a carreira do praticante nem a programação futura da entidade empregadora.

Por fim, João Leal Amado, embora partindo da afirmação de que o pacto de opção a favor do clube não é benéfico para o praticante, não deixa de aceitar que este deva ser recompensado pela opção concedida ao clube.

Neste sentido, Baptista reforça a ideia quando interpreta que o preço do direito de opção é central na análise desta temática, inclinando-se a considerá-lo inválido se, uma vez estabelecido a favor do clube, o praticante desportivo não retirar qualquer benefício.

\section{CONCLUSÃO}

As especificidades dos contratos de trabalho desportivos têm, pois, absoluta pertinência, dadas as situações que deles decorrem.

Pertinente, também, é o contínuo desenvolvimento e aperfeiçoamento das regulamentações legais que regem a matéria, para que os direitos e deveres dos praticantes desportivos e das entidades empregadoras estejam sempre salvaguardados.

A autonomia das partes tem cada vez mais relevância na elaboração destes contratos pois neles podem ser apostas cláusulas que em situações normais seriam inaceitáveis, com o objetivo de se manter o equilíbrio das competições desportivas e a estabilidade contratual. 
Tal autonomia, no entanto, não deve ser interpretada como arbitrariedade e/ou desproporcionalidade da fixação de condições contratuais, como já foi mencionado, mas como um instrumento de preservação das especificidades que esta modalidade requer.Relativamente ao pacto de opção, apesar de entender o enquadramento que João Leal Amado faz, julga-se ser demasiado pesado, pois o autor interpreta que respetivo pacto é sempre utilizado como instrumento de fraude à lei.

Ora, apesar de se ter de levar em conta a eventualidade da ocorrência dessas situações, optamos por acreditar na boa-fé dos contratantes, que somente utilizam esta ferramenta com o intuito de melhorar as condições laborais e assegurar o equilíbrio contratual e o seu cumprimento.

\section{REFERÊNCIAS}

AMADO, João Leal. Contrato de Trabalho Desportivo - Lei no 54/2017, de 14 de Julho - Anotada. Almedina, 2018.

BAPTISTA, Albino Mendes. Estudos sobre o contrato de trabalho desportivo. Coimbra Editora. Março, 2006.

PORTUGAL. Lei n. 28, de 26 de junho de 98. Estabelece um novo regime jurídico do contrato de trabalho do praticante desportivo e do contrato de formação desportiva e revoga o Decreto-Lei n. ${ }^{\circ}$ 305/95, de 18 de Novembro.

PORTUGAL. Lei n. 99, de 27 de Agosto de 2003. Código do Trabalho.

PORTUGAL. Lei n. 7, de 12 de fevereiro de 2009. Código do Trabalho.

PORTUGAL. Lei n. 54, de 14 de julho 2017. Lei do contrato do trabalho desportivo.

CARDENAL CARRO, Miguel. Deporte y Derecho: las relaciones laborales en el deporte profesional. Universidad de Murcia, 1996.

COSTA, Mário Júlio Almeida. Direito das Obrigações. 12. ed. rev. E atual. Almedina, 2009.

FERNANDES, António Monteiro. Direito do Trabalho. 19. ed. Almedina, Coimbra, 2019. 
PINTO, Mário; MARTINS, Pedro Furtado; CARVALHO, António Nunes de. Comentário às leis do trabalho. Volume I, Lex, Lisboa, 1994.

Data da submissão: $23 / 01 / 2020$

Data da aprovação: 20/07/2020 